\title{
Values-Based Practice When Engaging with Voice-Hearers
}

\author{
Rosalind Austin
}

\subsection{Introduction}

This chapter draws on the stories of two people, Paul and Mary, to explore the values arising in voice-hearing and how they may be addressed through the resources of values-based practice.

I met Paul and Mary and heard their stories as part of my doctorate work with Durham University's 'Hearing the Voice' project, a large interdisciplinary research team that seeks to explore the widest possible interpretation of what it is to hear voices. For my doctoral project, I interviewed 30 voice-hearers, who I largely recruited from two community mental health centres in North-East England and South-East England. Paul and Mary were two of these. This chapter describes in their own words their very different experiences of voice-hearing and what these experiences meant to them. Employing the inclusive definition of values adopted in values-based practice (as what matters or is important to those concerned, see introductory chap. 1), the chapter explores what mattered or was important respectively to Paul and Mary about their voice-hearing, and the influences on them of their respective cultural contexts.

In mental health contexts, voice-hearing is often treated merely as a negatively evaluated symptom to be treated as a disease. Conversely, among mental health advocacy organisations, voice-hearing is sometimes celebrated as a positive and rewarding experience. The headline finding from my study was that the realities of voice-hearing are far more complicated than either of these extremes. It involves complex and sometimes conflicting values, of the person concerned, and of others around them. Paul and Mary's stories illustrate this reality.

\footnotetext{
R. Austin $(\triangle)$

Collaborating Centre for Values-Based Practice, St Catherine's College, University of Oxford, Oxford, UK
} 


\subsection{Paul's Story}

Paul, an ex-soldier in his early 30s who is now unemployed, hears the voice of a defined character he calls 'the Captain'. In the interview, Paul said:

A lot of other voice-hearers have 'a voice'. It is somebody different from themselves. With me, it is just myself. I visualise him as me but with a scruffier beard and different attire and things like that [...] He looks different to me. He's quite aggressive, quite an old-school man's man. That's how he comes across [...] It's just there 24/7, always talking away to myself, getting replies and all this. That's just the way it is now. Some voice-hearers can put their voices away. Some tell them, 'I don't want to speak to you at this moment, could you come back later on?' With mine, it's just part of me, I'm like a Siamese twin, but on the inside.

Paul views his voice at times as being like a person. It is a characterful voice, 'an old-school man's man', who has his own distinct appearance, dress sense, and emotive aspect, with the voice being aggressive. It thus offers an example of a voice that has a distinct character with internally individualised agency, one of four levels of agent-representation in auditory hallucinations, or voices, described by the psychologists Wilkinson and Bell's [1] exploration of voices as social agents [2].

Paul draws attention to how his voice is internalised: it is 'just part of me'. He emphasises this connection by saying that the voice is 'a Siamese twin [...] on the inside'. The logic of the 'twin' here suggests that Paul has an intimate relationship with the voice, viewing it as internal and conjoined to him. Notably, he earlier claimed that it is 'my own voice but in different tones', which also suggests that he understands himself to be having a relationship with a voice that is at some level part of himself.

Later in the interview, Paul develops the image of the voice by saying that it 'was the captain of the ship really'. Such a characterisation has links to Paul's military background, and it is a military image that he uses to invoke the imbalance of power in his relationship with 'the Captain'. The latter's voice triggers fear and anxiety; Paul said, 'He [the Captain] was on the bow, making all the decisions and I was just there in the background watching him.' Here, Paul is describing an intimidating relationship where the voice has the power to watch him in a spectatorial way. Paul does not seem able to establish any firm boundary with the voice, where he might manage to get control, and he listens to it all day long. As Marius Romme (a psychiatrist) and Mervyn Morris (a psychiatric nurse) suggest, many voice-hearers who become psychiatric patients 'were afraid of their voices, overwhelmed by them, and felt powerless' [3, p. 2].

Paul took antipsychotic medication, but continued to hear the voice of the Captain. He sets aside times to listen to the voice, as it provides companionship for him. In my interview with him, he told me that he spent time doing different activities - such as fishing — when he would time-share with the voice. Paul understands fishing in a creative way, as within the context of doing this activity, he is able to engage in a dialogic relationship with the voice, so that he is less afraid of it. Noticing that the voice enjoys fishing too, Paul is distracted by it to the point where he would 'miss a bite' of a fish on the line. Despite his irritation, Paul is relieved that 
he has found 'something that we both enjoy'. Until now, there has been little common ground with his voice, so fishing is helpful in that it offers Paul a way of relating to his voice differently as he 'sit[s] on a bank'. The Captain's protective role, which is to 'stop me getting bullied in the future', switches to one of being a companion, and is described by Paul as being a 'family member you love to hate'. This reduces Paul's anxiety, so that he can have 'a good laugh'. This suggests again that the voice is a person-like entity who in fact benefits from being entertained.

The voice came to have importance to Paul. It is clear in the context of the interview that the voice mattered a good deal to him. What mattered to Paul was to be able to share a joke with the voice, and for it to function as a companion.

\subsection{Values in Paul's story}

A number of important values are evident or implied in this story, both Paul's values and the values of other people.

\subsubsection{Paul's Values}

As to Paul's values - as to what mattered or was important to him - it is clear from the story above that The Captain was at least in part a positive aspect of his life. Moreover, when I met Paul during the interview, it seemed that the voice caused him no problems with other people, at least with the general public. For example, Paul sometimes reacted to the voice by talking to it out loud when he was shopping in his town-but this had no untoward consequences in terms of other people's reactions.

That people's voices are often (as with Paul) benign or even sometimes positive is widely ignored even though the evidence has been available for many years [4]. It is clear from Paul's story that while he wished to listen to and respond to his voice on a regular basis, this was perceived negatively by many of those around him.

\subsubsection{Other People's Values}

Paul nonetheless did have problems in other areas reflecting other people's negative evaluations of voice-hearing. In another part of the interview, for example, he recounted how he was denied custody of his child; and his ex-wife used his mental health as a reason for barring him access. Similar views about frequent voicehearing being unacceptable are widely adopted in mainstream Western society. This is why Paul's ex-wife was supported by his medical team and the family court in considering that Paul needed to have medical treatment to suppress or eliminate his voices; and they argued that when Paul is actively hearing voices, his ability to care for his young daughter is compromised. Paul was sad that he was not trusted with the care of his daughter. 
But if Paul's talking back to his voice really 'caused no problems', was it ethical (or legal) to restrict Paul's responsibilities, including his parenting rights? Did Paul's ex-wife and the family court find Paul's verbalised to-and-fro conversation with his voice alarming? Were the lawyers and medical staff who wrote reports being pressurised 'to do something about' Paul's voice-hearing experience? Were there significant safeguarding issues regarding Paul having custody of his child? Any or all of such negative values are likely to have been in play.

Yet staff must have been well intentioned in the actions they took. In professions like psychiatry, this generally means treating voice-hearing as a hallmark symptom of schizophrenia or some other form of psychosis [5]. It is thus assumed to be a bad thing whatever the person concerned thinks.

These considerations remind us of the practical impact of The Two Feet Principle of values-based practice, that values as well as evidence are important in all aspects of health care decision-making: this includes, often crucially, as in Paul's story, diagnostic assessment $[2,6]$. What this means in practice is that even if a medical model were an appropriate way of understanding Paul's story, understanding what mattered or was important to him about his 'symptoms' would still have been vital to any decision about how to 'treat' them.

\subsection{Mary's Story}

Mary is in her late 50s and is a retired staff nurse. She worked as a nurse for 30 years. For 12 of these years, she heard voices at times when she was working on a medical ward in a busy hospital. Mary is very reflective about the way that she consciously shut down her emotions when she was working in a highly stressful working environment where 'people die'. She said:

Once I was engrossed in work, I could keep going. But it was difficult. I mean, you shut down your emotions because you've got people working on a medical ward, and people die. They die. But you've got to get on with your job. So you can't be emotionless, but you've got to shut it out somewhere. And I was shutting down completely. I did what I had to, you know, tell relatives or whatever. But I had nowhere to go with that as a nurse. And all these emotions built up and up and up. So by the time I had the operation in 1999, they were there...they were at their height.

Mary is here describing a strategy widely adopted by staff working on medical wards to keep their emotions in check so that they can do their jobs. Deaths on the ward are expected, and as Mary puts it, 'you've got to get on with your job'. However, in Mary's case, she was 'shutting down' her emotions completely. Given that she frequently worked nights and was the nurse in charge of the ward, she found it helpful to feel in control of the space as far as was possible, by having 'the door shut', as she didn't 'want people walking in and all the rest of it'. She would also 'stick to a routine', when dispensing medication to patients. Mary recalls that if 'I had it all organised I knew I could cope with it, and that way I could keep my emotions at bay, suppressed, because that's it, I've got everything organised'. Later in the interview, she said that 'the best way I've seen it [the shutting down] ever 
explained, was someone explained it to me as Data in Star Trek. The robot who wants his emotions.'

This particular robotic image that Mary selects indicates a perceived fundamental lack of emotions. Mary reflects that 'when I was working, I didn't realise how much I was suppressing'. In the above extract, Mary said that her 'emotions built up and up and up', and yet she had no one with whom to share her feelings. She said that 'one of my bugbears of let's say adult nursing is that they don't get any debrief'.

However, it was not until her late 30s when she experienced an 'acute stressor' in the form of undergoing life-threatening, major surgery, that Mary started to hear voices. There can be a 'sleeper effect' of trauma [7], where the person does not process the trauma emotionally at the time it actually takes place. In Mary's case, the stress of undergoing 'two major operations, which nearly killed me' was compounded by her being in a vulnerable, dependent state as she 'couldn't move off the bed, and I was being fed'. She was also on morphine, which altered her mental state. Many people experience delirium in intensive care units $([8,9])$. In Mary's story, the situation was further complicated by what she later revealed about her 'childhood trauma' of being sexually abused by 'a very respected member of the community' when she was a young girl.

Mary's story is in this respect consistent with the psychiatrist Judith Herman's [10] observation that survivors of abuse may successfully cope with adult life until defensive structures break down due to a very stressful event (like the operation). Mary was later encouraged by a psychiatrist to make the connection between her childhood experience of abuse and the voices that she hears. Following a change of diagnosis from schizophrenia to personality disorder, Mary went on to have 3 years of intense psychological support by attending group therapy run by a psychologist, organised by a Complex Needs Service.

\subsection{Values in Mary's story}

As with Paul's story, it is helpful to consider Mary's values and how these interacted with those of others around her.

\subsubsection{Mary's Values}

Although a very different narrative from Paul's, Mary's story raises many of the same considerations from the point of view of values-based practice: the importance of the values of others, of attending carefully to what matters or is important to the person concerned, and of balanced decision-making A central difference however is that where Paul valued his voice positively, Mary valued her voices negatively.

Mary identified how one of the male voices that she heard represented the anger that she was unable to feel or articulate. She suggested that her suppressed emotion came out in this voice, and she calls it 'Mr Angry'. Mary acted out how 'Mr Angry's with me today', by storming around looking angry. Thus, where Paul's voice was 
internalised, Mary describes her voice as having an external reality, in that she conceptualises it as being like a person who accompanies her. Mary said that other members of the complex needs group she joined (who knew that Mary was a voicehearer, and permitted her to 'bring her voices into the group') were relieved that she was able to make this connection between her emotion and her voice, as it explained her behaviour.

\subsubsection{Other People's Values}

Mary's story highlights a further crucial set of values for values-based practice, namely of the multidisciplinary team, specifically, in Mary's story, the complex needs team. In values-based practice, different team members (i.e. a psychiatrist and a psychologist) bring to clinical care not only a range of knowledge and skills but also a range of values [11]. This range of values is important as a resource for meeting the corresponding range of values presented by patients. This in turn contributes to balanced decision-making on person-values-centred care.

The 'team' in values-based practice though is not limited to health and social care professionals, but may include many others with a role to play in a given situation. Thus, housing, education, and other professionals may often have key contributions to make (for examples, see ref. [12]). Crucial, though, in addition, may be the contributions of peers with shared experience. In Mary's story, the members of the complex need group with whom she worked included 'peers'. In this, Mary's voice-hearing was accepted thus normalising her voices, in stark contrast to the hospital setting, where Mary suppressed her voices and emotions so that she could work effectively as a nurse. When Mary first began to hear voices, as a patient in the intensive care ward after her operation, she felt that it was not safe to share this (as she perceived it) stigmatised experience.

Rather strikingly, however, as she reported, none of the peer members of her Complex Needs Group actually shared her experience of hearing voices. There was thus no 'shared' peer knowledge of coping strategies for voice-hearing of the kind to which Mary would have had access had she attended a hearing voices group. (For more on Hearing Voices Groups please see the Guide to Further Sources, below.)

\subsection{Conclusions}

In this chapter, I have explored through the stories of two voice-hearers, Paul and Mary, the wide range of values raised by voice-hearing and the correspondingly wide range of applications of values-based practice. I began with a close reading of Paul's story to bring out the key values involved in terms of how voice-hearing is understood and worked with. This illustrated the practical impact of the Two Feet 
Principle of values-based practice that values are important in all aspects of health care decision-making. The second close reading of Mary's story then raised awareness of the diversity of voice-hearing, and why it is important to engage effectively with individual values. In this individual case, the skills and values of the multidisciplinary 'team' were required, and then, the values of a complex needs group, which led to Mary feeling that her experience of voice-hearing has been normalised. In this setting, she has learnt to live well with her voices and her emotions, which in her opinion are inextricably bound together.

Acknowledgements I am grateful to Durham University's 'Hearing the Voice' project for the grant that I received from them to fund this doctoral research.

\subsection{Guide to Further Sources}

Please find below links to websites that give further information on voice-hearing, and what support is available. These resources are helpful for those who hear voices, as well as for mental health professionals and researchers.

Educational Voice-hearing Network, Collaborating Centre of Values-based Practice, St Catherine's College, Oxford University-https://valuesbasedpractice. org/what-do-we-do/networks/educational-voice-hearing-network/

Soundscape with voice-hearers-https://valuesbasedpractice.org/what-do-wedo/networks/educational-voice-hearing-network/soundscape-with-voice-hearers/

Durham University's 'Understanding Voices' website-https://www.dur.ac.uk/ imh/understandingvoices/

Durham University's 'Hearing the Voice' website—https://hearingthevoice.org/

London Hearing Voices Network website-http://www.mindincamden.org.uk/ services/lhvn

\subsubsection{Hearing Voices Groups}

Voice-hearers seek support from peer support groups for voice-hearers, known as 'hearing voices groups'. The Hearing Voices Movement emerged as 'a web of selfhelp groups offering assistance to troubled voice-hearers' [13, p. 6]. In England, there are now over 180 hearing voices groups held in a range of settings, including mental health services, inpatient units, and prisons. Over the past 20 years, hearing voices groups have been set up throughout Europe, North America, Australia, and New Zealand, with 'emerging initiatives in Latin America, Africa, and Asia' [12, p. S285]. The "main tenet of the Hearing Voices Movement is the notion that hearing voices is a meaningful human experience [12, p. S285]. However, within this movement, members have a diversity of explanations (e.g. spiritual, telepathy, psychological) for what voices represent. 


\section{References}

1. Wilkinson S, Bell V. The representation of agents in auditory verbal hallucinations. Mind Lang. 2016;31:104-26.

2. National Institute for Mental Health in England (NIMHE) and the Care Services Improvement Partnership. 3 Keys to a shared approach in mental health assessment. London: Department of Health; 2008. Available as a free full-text download from the Collaborating Center for Valuesbased Practice at: http://valuesbasedpractice.org/. More about VBP/Full text downloads/scroll down to 3 Keys).

3. Romme M, Morris M. Introduction. In: Romme M, Escher S, Dillon J, Corstens D, Morris M, editors. Living with voices: 50 stories of recovery. Ross-on-Wye: PCCS Books; 2009. p. 1-6.

4. Johns LC, van Os J. The continuity of psychotic experiences in the general population. Clin Psychol Rev. 2001;21(8):1125-41.

5. Waters F, Allen P, Aleman A, Fernyhough C, Woodward T, Badcock J, Barkus E, Johns L, Varese F, Menon M, Vercammen A, Laroi F. Auditory hallucinations in schizophrenia and nonschizophrenia populations: a review and integrated model of cognitive mechanisms. Schizophr Bull. 2012;38:683-92.

6. Fulford KWM, Dewey S, King M. Values-based involuntary seclusion and treatment: value pluralism and the UJK's mental health act 2007. Ch 60. In: Sadler JZ, van Staden W, KWM F, editors. The Oxford handbook of psychiatric ethics. Oxford: Oxford University Press; 2015.

7. Page G, Kurth T. Delirium on the intensive care unit. Brt Med J. 2014;349: p7265. Available at: https://doi.org/10.1136/bmj.g7265.

8. Girard D, Pandharipande P, Ely E. Delirium in the intensive care unit. Crit Care. 2008;12:1-9.

9. Briere JN. Child Abuse Trauma: Theory and Treatment of the Lasting Effects. London and New York: Sage Publications; 1992.

10. Herman J. Trauma and recovery. London: Pandora; 2001.

11. Colombo A, Benedelow G, Fulford KWM, et al. Evaluating the influence of implicit models of mental disorder on processes of shared decision making within community based multidisciplinary teams. Soc Sci Med. 2003;56:1557-70.

12. Corstens D, Longden E, McCarthy-Jones S, Waddingham R, Thomas N. Emerging perspectives from the hearing voices movement: implications for research and practice. Schizophr Bull. 2014;40:285-94.

13. James A. Raising our voices: an account of the hearing voices movement. Gloucester: Handsell Publishing; 2001.

Open Access This chapter is licensed under the terms of the Creative Commons Attribution 4.0 International License (http://creativecommons.org/licenses/by/4.0/), which permits use, sharing, adaptation, distribution and reproduction in any medium or format, as long as you give appropriate credit to the original author(s) and the source, provide a link to the Creative Commons license and indicate if changes were made.

The images or other third party material in this chapter are included in the chapter's Creative Commons license, unless indicated otherwise in a credit line to the material. If material is not included in the chapter's Creative Commons license and your intended use is not permitted by statutory regulation or exceeds the permitted use, you will need to obtain permission directly from the copyright holder.

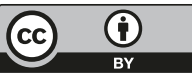

